\title{
ESTONIAN YOUTH WORK EXPERTS PROFESSIONAL GROWTH: CASES STUDY
}

\author{
Maarika Veigel \\ Tallinn Health Care College, Tallinn University, Estonia
}

\begin{abstract}
Estonian youth work (YW) has been in development almost 30 years. In the last more than 15 years the same trends have been observed in the studies in terms of professional development: the shortage of employees with professional education and workers high mobility. At the same time, the progressive decisions and regulations made in Estonia, on the field of European YW are exemplary. Thus, the prerequisites for professional YW were created and experts in the field have also developed.

The aim of research was to give an overview of the stories of becoming as experts. Semistructured interviews were compiled in 2019. Special focus was on the professional growth in the content of life story. The study revealed both - randomness entry into $Y W$, but various supporting external aspects (active school life, supportive community, camps). However, the most important were the personal factors - motivation, consistency, entrepreneurship, courage, YW studies, participation in (foreign) projects, mission. Professional knowledge and skills supported mostly the development from a novice specialist into an advanced employee and expert. Commitment, autonomy were the main work-load impact factors. The desire to work with young people has brought some retired youth workers back to YW. Horizontal career was limited but usual.
\end{abstract}

Keywords: Estonia, expert, professional growth, youth worker.

\section{Introduction}

The OSKA report "Work and Skills 2025” (Pärna, 2018) stated that the development of Estonia and organizations is hampered by the constant decrease in the number of employees; the environment in which organizations operated was extremely fast-changing. Continuous learning for both organizations and individuals was essential to cope with change. This research focuses on becoming an expert through the continuum of working life, explaining the factors influencing YW and youth worker. As the conditions for the existence of professionals have been created in YW and high expectations for the field, it was appropriated to analyze the success stories related to professional growth from youth workers to experts. 
Berliner presented development model of competency levels, treats the professional development as long term, complex process, distinguishing between the five stages of development of the professional staff, which are also regarded in the context of the professional development of the youth worker. Professional growth supports workers' job performance. That is a continuous learning process to acquire the knowledge and skills needed for working life, which will be used more competently to meet the changing requirements of the agency (Veigel, 2015; Ruohotie, 2005)

During 2005-2019 various studies explained the high mobility of Estonia youth workers in youth centres and shortage of personnel with special education. Considering the above, professional youth workers will need long-term employment in the sector to develop their skills (Veigel, 2020; Conradsen, 2017; Veigel, 2015). In order to ensure the quality and development of YW, the youth worker should constantly improved himself in addition to his main job, a socalled continuous process of self-improvement. Thus, the focus was also on the lifelong learning strategy. The research problem was contradiction: due the frequent changes in YW staff, but good results in YW regulations and recognition at European level, was necessary to study the youth workers' professional growth, exactly meaningful patterns and development at the expert level.

The aim of this research was to give an overview of the stories of becoming as YW experts. The key questions were: (1) which characterizes entry into YW and the development of a novice worker? (2) What were the significant aspects of working as a youth worker? (3) What were the expert's strategies, goals and future vision?

\section{Literature Review}

It is important to know that YW has been taught in Estonia since 1992. First at the Tallinn Pedagogical College. Today at Tallinn University, where in addition to the applied higher education of a youth worker, you can obtain a master's degree in the field of YW organization. But long-term research in Estonia showed that many youth workers were without professional education (Käger, Kivistik, \& Tatar, 2017), their professional identity and professional development, as well as professional skills, were questionable.

Possibilities of becoming a youth worker are very different. Sapin (2012) added learning through informal and non-formal learning to the formal education of a youth worker. Emphasis was placed on the possibility of getting a student, a hobby enthusiast in informal learning, to gain access to YW. Also important was the role of non-formal learning: training, workshops, networking, 
self-improvement. Formal learning curricula, courses based on structured curricula as starting points for learning youth workers.

Youth workers started work for reasons, because it seemed like a routinefree, versatile, still lesser-known profession, interesting work with young people. They started with an enthusiasm, but then, as expected, it become clear that dealing with the content of YW and it is based on important professional level knowledge and training. The work of a youth worker remained hard as it is multi-functional, full of various activities, emotional and physical tension. The requirements to the youth worker's professional level, activity and behaviour were high and very difficult to meet due to the pecularities of this profession. (Veigel, 2019). However, this study focused on becoming an expert in YW.

On the level of expertise (expert level) people act more quickly, flexible and smoothly. Experts be able to intuitively perceive situations and make the right decisions without any further analysis or discussion. The simplest methods of teaching (action) operations are carried out automatically, leaving more time to immerse themselves in the most important problems (Okas et al., 2014). According to Berliner competency levels of the development model more adept worker is the one of 4-5 years of service. As there is a large mobility in the YW sector, according to this model the number of youth workers reached the last three steps (competent, experienced employee, expert) is obviously small. Youth worker occupational levels 4 and 6 correspond to the first two steps of the described model specifications. However, if the daily practice of the youth worker professional level 6 was in the authors' opinion, or rather, as expected, a competent or experienced employee level and level 7 explained / considered by the expert level (Veigel, 2015). It turned out that, YW experts must express about work achievements, their needs confidently and more loudly. Working in the local government set a certain framework for experts, who understood the content of the $\mathrm{YW}$, but it was hard to training and mentoring many new colleagues constantly. Collegiality and organizational culture supported employees, but attention should be pay more to the other elements of professional growth (personal and work-load factors), too (Veigel, 2020).

Any professional identity is formed by the combination of studies, work experience and the environment (Gibson, Dollarhide, \& Moss, 2010) and perhaps the beginning of its' formation may be previously conscious information and experience (Johnson et al., 2012). Professional identity is constantly changing and its' formation begins with becoming a member of the professional community in a social context (learning, communicating) (Van Lankveld et al., 2016; Slay \& Smith, 2010) and cooperation. It is important to 
understand the professional future perspective. Supporting the development of a professional identity is an important task for experts. They could certainly serve as role models for their nascent colleagues. Experts had a strong professional identity supported by professional development. Most of them worked before as youth workers. Experts understood the content of the field, but it is hard to train and mentoring many new collegues constantly (Veigel, 2019).

Professional practice is dynamic. Practitioners are constantly shaping their practice by thinking and interpreting, creating and re-engaging (Dall'Alba \& Sandberg, 2006). Eraut and Hirsch (2007) demonstrated that the majority professional learning is embedded in normal work. In the reality it is everyday work with thinking about it (reflection), cooperating with their collegues, sharing their ideas, and improving their own as well as their youth performance. It meant that collegues were absolutely necessary, but in Estonia many youth workers worked alone or half of work-time. Professional growth basic elementspersonality factors, work-load and tasks' factors and organizational factors (Ruohotie, 2005) were definitely to be taken into account when considering the development related to the growth of employees, both from a personal and institutional point of view.

The research explained, which characterized entry into YW and the professional development of a novice youth worker; what were the significant aspects of working as a youth worker and in professional growth in continuum to expert level; what kind strategies, goals and future vision experts valued.

\section{Methodology of Research}

This research applied a qualitative research strategy, based on a phenomenological approach. For qualitative data collection semi-structured interviews were conducted with 6 Estonian YW experts (2 man, 4 women) individually in 2019. They lasted usually from 1 to $1,5 \mathrm{~h}$ and were recorded on tape. The interview took place in a social context. Both the interviewer and the interviewee brought to an interview with their past, age, position, expectations and beliefs (Singleton \& Straits, 2012) to elaborate on aspects related to professional growth and explain its' different ways. A qualitative research method is justified, because the author investigated peoples' judgments and interpretations of the phenomenon (youth work experts' professional growth and its' influence factors). In the focus of the research was youth work experts' professional growth. The research results briefly described the professional activities and growth of the interviewees (codes I1, etc.). A discussion was then conducted with illustrative examples from the interviews. The anonymity of the sample was ensured. Protecting participants and respecting their right to make 
decisions regarding their participation were the core ethical principles guiding the treatment of the participants in the research. Participation was voluntary and all were informed of their right to withdraw at any time without consequences. No sensitive questions were asked. Saturation of the data was achieved.

\section{Research Results}

The interviewees had more than 8 years of experience working in YW, three 11-18 years. The following were brief descriptions of the working lives of YW experts (cases I1-I6) to elaborate better on aspects related to professional growth:

I1 - was an active student at school. The study of YW was consciously chosen because it was a new specialty at that time and many electives disciplines seemed very interesting in the curriculum. The internships supported the attachment. He has worked as a youth worker all the time, but in several different youth centers. He twice found it disturbing to see the change in the city's structures when many colleagues left, so the network collapsed. The high mobility of co-workers still disturbs, because together with the manager, he felt like a professional. Evaluates flexible use of time at the agency, possibility of additional work, related to sports activities. Recently, there has been more focus on young people aged $18^{+}$, such as movie nights, hikes, etc. The personal influence is the desire to work with young people, to apply experience. Interviewee wanted to work in the youth field in the future. It is selective in terms of training, as there have been many and the same number of (replacement) employees. The professional level of the youth worker is not considered important.

I2 - was an active, good student during school. YW came to his studies by chance, on the recommendation of a friend, because she wanted to study in Tallinn. The studies were interesting, she liked the internships and gave an impetus to stay in the profession. She first started work as a youth worker and considered this period very inspiring, active, because he liked to thougth "out of the box", considered the values of YW, analysis, reflection, cooperation, directed paperwork to be in order, a good time planner. Has received recognition. For a few years she was the head of a youth center, but it was difficult to got employees, their great mobility was tiring, it caused outrage. In recent years, she has been working at the local government level as a YW coordinator and continues to work in the field. She had completed master's studies in a related field, the skills of which can be successfully used in youth 
work. Consistency, patience, communication skills, project preparation skills, language skills, values (eg healthy lifestyle) were considered supportive.

I3 - at a young age he was an active but rather unsuccessful student. He consciously chose to study YW and values the time he has studied as the best in his life, because he had a positive learning experience. During his professional studies, he was active as a youth leader at home county. Later became a youth worker. Due to the lack of human resources, the organization of events was complicated and willow thoughts remained on paper. The enthusiasm of the young people supported their retention, but from time to time they also did additional work due to the higher demand for salaries. When the head of the youth center became vacant, he started working as a manager, but as the local government did not value the field enough, he left the school as a hobby manager. He liked to work with young people and wanted to continue practicing international and smart YW. Graduated with a master's degree, but was not sure about further work in the field. Saw a great danger of burnout and altruism in YW.

I4 - was an active, funny young person during school time, who studied various professions after basic school, but accidentally she got to learn YW studies. The studies were interesting, but it was easy to learn. She highly appreciated the abundance of internships, internationalization, new acquaintances, does not easily say "no" and did things rather than postponed things. Has worked throughout the period at the local government level, coordinated the field of YW in several areas. Knew the regulations in the youth field very well, but in terms of demanding she had to push herself. Understood that youth workers without special education were often unable to capture the content of the field for quite a long time, considering it rather a moody job. She also called the work that had become routine and a bit boring the intermediate period, which was why she started studying for a master's degree. She was active in a youth workers' organization. Took note of what is happening in the field very calmly, in the future will work in YW.

I5 - was as an active young person, she wanted to start studying YW based on the example of her school's hobby leader. Unfortunately, in the second year of studies, she thought that she already wanted to do practical work and started working as a youth worker in a youth center, which had a very bad reputation in the city, which was walked by a large arc. Personal initiative and possilbility to saw the whole picture, supported from friends, she good communication skills, the ability to maked herself heard in the city administration, activity - led to more and more progress. The position of youth workers was added, better payment, co-operation with the police, child protection, the Defense League and other supporters improved, and the culture of young people and organizations 
also improved. If was possible, she took on the role of the head of the youth center. A multicultural supportive environment has been created in which young people wanted to come and contribute to activities. Many major events had become a tradition and the community has participated in it. Although half of the professional studies were still done, the youth worker has a professional level of 6. She only saw herself working in YW at the moment.

I6 - as a modest, good student, she was expected to go to university, but could not get in and, on the recommendation of a friend, found her way to study YW. It was a thorough, good, favorite of teachers in specialty studies. The first job was one of the internship bases, where the familiar environment supported the novice employee. Through the guidance of the trainings, young people were better involved. It was good to get along with colleagues. Unfortunately, she left work when the city made structural changes. She started working in a close profession for a few years, but still met with his former "difficult" young people to discuss daily topics and activities in cafes. After a few years, she wanted to start working as a youth worker again, and although the distance between home and work was quite large, she found motivation to work with young people again. The manager highly valued her work, received recognition in the field. She described herself as a rather modest girl. She was a lot involved in trainings and international youth exchanges. Later, if possible, she started working at the local government level. Evaluated the educational goals in YW and was able to realized them through well-managed projects.

Reaching to youth work and specialty studies. The interviewees reached YW either through participation in supported hobbies as a student at school and its' influences (cooperation with the hobby leader, personal activity), or as a random choice in favor of YW studies. / I was very active during school, I dealt with many things.//The hobby guide suggested that I start learning it./ There were even completely random people there /..because there was no other option.// .. someone else suggested, thought I was suitable for it to the specialty/. For many interviewees YW was important and exciting as a new field./ Then I just started level studies in youth work and I thought it suited me. Most youth wanted to start studying in Tallinn /I didn't become a teacher, I started to study youth work.//I didn't want to go to Tartu, because I was as a type of organizer, then my friends also recommended me to start studying YW/. It turned out that acquiring higher education was very interesting for the majority. /I liked many subjects, such as psychology, electives, specialties, languages./ One interviewee emphasized, that he had a positive learning experience for the first time as a conscious learner, because he was interested and the cooperation with teachers 
was pleasant, professional. /There was also some flexibility, because many people were already at work/.

In addition to basic professional courses, emphasis was also placed on the abundance of elective studies, psychology and pedagogy, basics of educational sciences, development of language skills, and music studies. Some took part in ERASMUS study abroad, which gave them new acquaintances to engage in further projects and camps abroad. /As the internship bases were voluntary, I also got the confidence that I could go somewhere/. In addition to school, most of them went to work, mainly as customer service staff, but also as part-time students at a part-time youth center. Four of the interviewees later got an internship base, which was an important supporting factor, when the novice employee was already exposed to an familiar environment. /The job was familiar, many young people too. It was like moving on with your internship./ The youth center did not have a good image, because there were also problematic youth, who sometimes stayed there. Young people's different motivations, lifestyles, ages and interests have made work difficult./ At the beginning, it was more difficult to distinguish work from one's free time, because the activities were also interesting for oneself and seemed to be "immersed" in them. Sometimes relatives and friends were involved in their own work. If you organize and are responsible for the events, it is sometimes 24 hours a day/. There was overwork, which is often the case with camps, events, etc. /There is no working time for them, because the end of the event is a sign ... and then cleaning, etc./. Not everyone had first a positive experience of cooperation with schools, although young people were the same people. This was especially true in smaller counties. /So far, it's as if we're duplicating events sometimes, and the school's specialist doesn't seem interested in our things. However, young people are the same schoolchildren./ The abundance of training opportunities was positive, which was practiced later in working hours, ie trainers were also selected. /Now I'm already looking at who trains, because there are a lot of offers and there aren't so many manpower resources to train yourself often./ As young people were also graduates of the university, some of the interviewees had problems with self-assertion. Therefore, the so-called favorite age groups also developed, ie some liked to deal with young people at a younger school age more. /Many like younger children... Now we have a time distribution for different ages./ The professional skills acquired in the novice employee (in elective and optional subjects at school), supervision of trainings and camp work, preparation and management of projects became supportive; skills in using different methods, outdoor training and physical activities. /We got a very wide base, on which there were opportunities to move forward, start work, etc./. 
Novice employee were especially varied about the behavioral problems of young people. However, the approaches created for this through involvement had a positive result, shaping the rules, gaining trust. Advice from experienced colleagues or practitioners supported coping. /At the beginning with some young people, you just have to look-watch, gradually gain confidence. Some have to be fined - 1 week, put on./. In general, the oldest age group (18-26 years) is still little involved in youth work. /Some former students help to deal with a film club and liketo great the projects for older youngsters./

Transformation from a novice employee to an advanced employee. As working time and experience increased, strategies, approaches and more strengths emerged, including favorite activities. In general, all interviewees thought that they had rather pleasant colleagues, with whom they organized interesting events and created conditions to support the development of young people. IIf in the past some people were afraid to walk from this street late at night, now it is safe and the surroundings are in order. But we have the most young people of 4 nationalities.//The writing of projects increased because they need additional funding, and bureaucracy in general.//Represents to the city goverment often what we do./ All the experts had survived the changes in the local government at different times, when the established systems were dismantled, cooperation with colleagues and networks disappeared (changed). The departure of many colleagues was very demotivating. /I even thought I was going elsewhere.// Colleagues left and the mood was zero. I went to another job myself./ The high mobility of the staff has made it necessary to constantly adapt to new people. In addition, the group of young people is always different, ie varies according to age, gender, interests, also nationalities. The will to work with young people in the field, patience, challenges and thinking out of the box are considered more important. Communication skills are especially important (empathy, good use of humor, conflict prevention, cognition, ability to always be "present", ability to listen, feel barriers to communication, etc.). / You have to win the trust of young people and then it's fierce./ Many interviewees also had another job in parallel, either working in their own company or elsewhere. This has been partly due to salary, but also as a personal initiative and a desire to acquire an additional profession in another specialty, to offer a service, to use one's own special skills (art, photography, sports, as an event organizer). /I am also interested in photography and initially dealing with young people, but now also in my company.//I also organize children's birthdays.//I am a coach/. Half of the participants applied for a occupational level of youth worker 6 . Unfortunately, some do not consider it important, because the specialty has been 
studied and at the same time a few interviewees have chosen a master's degree in organisation of YW. One explanation /.to avoid the routine..I somehow started to get bored. I thought I was going to study./

Professional development of a youth worker to the level of an expert. It turned out that job changes within the sector were rather frequent. The positions were: youth worker, director / director of the youth center, local government youth work coordinator, etc. Two interviewees worked only as youth workers in different youth centers. Most of the interviewers participated in professional networks, but opinions differed on its' effectiveness. Some experts just wanted to do their job calmly. On the contrary, some can actively update YW at the local government level and develop it on the basis of knowledge. Targeting one's own work was based on various documents in YW. All saw the bigger picture of the youth field and the role of themselves in it further. Self-reflection is not done consistently, rather it is not given importance. It is also not considered important to apply for a youth worker level 7. However, one of the interviewees started a master's studies in YW management, and one of them had graduated last years. One interviewee also did not want to complete occupational level 6, has received high recognition for his activities in the field. Some participated in trainings and in the umbrella organization activities. One expert wanted to employ himself as a youth worker, not a manager, etc./ There is a lot of experience and you look like through the young people. Skills support and motivate young people to participate in $\mathrm{YW} /$.

\section{Conclusion}

Estonian YW was considered to be relatively young in Europe, while its' progress at the regulatory level is praised and cited as an example. Local government and YW specialists were responsible for the YW organization and development. They had high expectations, but it was not easy to prove themselves in the field, colleagues often lacked experiences in cooperation. The intrinsic motivation and professionalism supported the experts in their professional development and work. Working time, professional studies, activity, determination, communication skills were important factors in professional growth. Horizontal and vertical careers existed in YW and retained experts, as well as autonomy. Experts valued the profession and skills they learned, but they could be more enthusiastic about promoting innovation in the youth field. Sometimes it seemed too comfortable and routine complacency. The fact that the necessity of the field needed to be constantly proven was explained as an obstacle. Supporting a novice worker during his career must be more at focus. The used strengths and skills, correct methodology and safe work with 
young people, supported achieving contacts, involved young people, reached goals in general, and wanted to work in YW in future. The use of different tools in their work would be important. Responsibility is the most motivating and arises when there is a choice.

\section{References}

Conradsen, N.B. (2017). Estonia. Taking the future into their own hands. Youth work and entrepreneurial learning. Annex 1: country reports. In Andersen, T., Hougaard, K.F. (Eds.). Directorate - General Education, Youth, Sport and Culture. European Commission, 90-97.

Dall'Alba, G., \& Sandberg, J. (2006). Unveiling Professional Development: A Critical Review of Stage Models. Review of Educational Research, 76(3), 383 - 412.

Eraut, M., \& Hirsch, W. (2007). The significance of workplace learning for individuals, groups and organisations, SKOPE Monograph 9, United Kingdom.

Gibson, D. M., Dollarhide, C. T., \& Moss, J. M. (2010). Professional identity development: A grounded theory of transformational tasks of new counselors. Counselor. Education and Supervision 50(1), 21-38. Retrieved from https://doi.org/10.1002/j.15566978.2010.tb00106.X

Johnson, M., Cowin, L, S., Wilson, I., \& Young, H. (2012). Professional identity and nursing: contemporary theoretical developments and future research challenges. Nursing Review, 59(4), 562-569. Retrieved from https://doi.org/10.1111/j.1466-7657.2012.01013.x

Käger, M., Kivistik, K. \& Tatar, M. (2017). Noorsootöötajate koolitusvajaduste uuring. Balti Uuringute Instituut ja SA Archimedese Noorteagentuur. Retrieved from https:/mitteformaalne.ee/wpcontent/uploads/2018/

Pärna, O. (2018). In O. Pärna (Ed.), Töö ja oskused 2025. (Work and skills in 2025). SA Kutsekoda. Retrivied from http://oska.kutsekoda.ee/wp-content/uploads/2016/ 04/Tulevikutrendid-1.pdf

Ruohotie, P. (2005). Oppiminen ja ammatillinen kasvu. (learning and professional growth). Helsinki: Werner Söderström Osakeyhtiö.

Sapin, K. (2012). Essential skills for wouth work practice. SAGE PUBLICATIONS Ltd.

Singleton, R. A. \& Staits, B. C. (2012). Survey interviewing. Interwiev research. The SAGE Handbook. In Gubrium, J. F., Holstein, J. A., Marvasti, A. B., Mc Kinney, K.D. (Eds.), Library of Congress Cataloging in Publication Data. United States of America, 77- 98.

Slay, H. S. \& Smith, D. A. (2011). Professional identity construction: Using narrative to understand the negotiation of professional and stigmatized cultural identities. Human Relations, 64(1), 85-107. Retrieved from https://doi.org/10.1177/0018726710384290

Van Lankveld, T., Schoonenboom, J., Kusurkar, R. A., Volman, M., Bieshuizen, J., \& Croiset, G. (2016). Integrating the teaching role into one's identity: a qualitative study of beginning undergraduate medical teachers. Advances in Health Sciences Education, 22(3), 601-622. Retrivied from https://doi.org/10.1007/s10459-016-9694-5

Veigel, M. (2020). Society. Integration. Education. Proceedings of the International Scientific Conference, (5), May 22. -23., 2020, Rezekne, RTA, 302-312. 
Veigel, 2021. Estonian Youth Work Experts Professional Growth: Cases Study

Veigel, M. (2019). Personality factors as basic elements of the Estonian youth workers'professional growth. Society. Integration. Education. Proceedings of the International Scientific Conference, (5), May 24. -25., 2019, Rezekne, RTA, 293-302.

Veigel, M. (2015). Formation of youth worker' professionalism: problems in Estonia. Problems of education in the 21st Century, 68, 84-96. 